\title{
Effect of sowing dates on the yield and seed production of Okra cultivars in Mansehra
}

\author{
Shah Zeb*, Qazi Shoaib Ali, Ehtesham Jamil, Naveed Ahmad, \\ Muhammad Sajid, Sajid Siddique and Muhammad Shahid \\ Department of Horticulture, The University of Agriculture, Peshawar, Pakistan \\ *Corresponding author's email: shahzeb hort@yahoo.com
}

Citation

Shah Zeb, Qazi Shoaib Ali, Ehtesham Jamil, Naveed Ahmad, Muhammad Sajid, Sajid Siddique and Muhammad Shahid. Effect of sowing dates on the yield and seed production of okra cultivars in Mansehra. Pure and Applied Biology. Vol. 4, Issue 3, 2015, pp 313-317. http://dx.doi.org/10.19045/bspab.2015.43006

Received: 30/04/2015

Revised: 06/07/2015

Accepted: 10/07/2015

\section{Abstract}

Generally, the farmers are realizing low yield due to many reasons such as, use of primitive cultivars, conventional sowing methods, improper sowing time, imbalanced fertilization, weeds infestation and ignorance of plant protection measures etc. Therefore, present study was undertaken to determine high yielding cultivar (s) as well as the most suitable sowing date to maximize per unit production. To monitor the effect of different sowing dates on the yield and seed production of okra cultivars, an experiment was conducted at Agricultural Research Station, Baffa Mansehra during 2008. Six cultivars of okra i.e. Irka, Sabz Pari, Pusa Green, Pusa Sawani, Sarhad Green and Green Star were sown on three different sowing dates with 15 days interval i.e. $15^{\text {th }}$ March, $30^{\text {th }}$ March and $14^{\text {th }}$ April, 2008. Maximum number of pods $\operatorname{plant}^{-1}(32.12)$, pod length $(11.12 \mathrm{~cm})$, pod diameter $(1.54 \mathrm{~cm})$, pod weight $(15.24 \mathrm{gm})$, plant height $(184.28 \mathrm{~cm})$, number of branches plant ${ }^{-1}(9.12)$, pod yield $\left(16.24 \mathrm{t} \mathrm{ha}^{-1}\right)$, seed yield $\left(1601.92 \mathrm{~kg} \mathrm{ha}^{-1}\right)$ and 1000 -seed weight $(86.92 \mathrm{gm})$ were recorded in cultivars, sown on $30^{\text {th }}$ March, 2008. Maximum number of pods plant ${ }^{-1}(32.75)$, pod length $(11.57 \mathrm{~cm})$, pod diameter $(1.67 \mathrm{~cm})$, pod weight $(16.04 \mathrm{gm})$, plant height $(187.17 \mathrm{~cm})$, number of branches plant ${ }^{-1}(9.25)$, pod yield $\left(17.50 \mathrm{t} \mathrm{ha}^{-1}\right)$, seed yield (1735.00 $\left.\mathrm{kg} \mathrm{ha}^{-1}\right)$ and 1000-seed weight (89.32 gm) were recorded in cultivar Sabz Pari. Sowing of okra cultivar Sabz Pari on $30^{\text {th }}$ March is recommended for realizing maximum fresh pod and seed yields under the agro-climatic conditions of Mansehra District.

Key words: Abelmoschus esculentus L.; genetic characteristics; sowing dates; okra cultivars; crop productivity.

\section{Introduction}

Okra or Lady's finger (Abelmoschus esculentus L.), locally known as Bhindi, belongs to the family Malvaceae. It originated in tropical Africa and was also grown in Mediterranean region and its wild forms are found in India. It is now grown in all parts of the tropics and during the summer in the warmer parts of the temperate region [1]. It is a popular summer vegetable in Pakistan and is especially valued for its tender and immature pods, which are rich sources of vitamins, calcium, potassium and other minerals. The marketable size of pods 
ranges 3 to 5 inches in length and is considered optimum for consumption. Plant growth and yield are both adversely affected if the pods are not harvested when young on regular basis. The average yield of green pods is about 8-10 tons ha $^{-1}$ [1] which is very low as compared to other developed countries of the world, where yield could reach as high as $30 \mathrm{t} \mathrm{ha}^{-1}$. [2] For seed production, the pods are allowed to dry on the plant, harvested periodically to avoid shattering of seed, and sun dried and threshed. The seed is dried to 8 percent moisture and stored in a dry cool place. Under normal storage conditions, seed remains viable for two years or so [3]. Different cultivars require different climatic condition as well as different sowing time and a good cultivar when sown at improper time give poor yield [4]. Therefore, proper date of sowing of a suitable cultivar is critical for enhancing crop productivity.

Generally, the farmers of the Mansehra District are realizing low yields due to many reasons such as, use of primitive cultivars, conventional sowing methods, improper sowing time, imbalanced fertilization, weeds infestation and ignorance of plant protection measures etc. Therefore, present study was undertaken to determine high yielding cultivar(s) as well as the most suitable sowing date to maximize per unit production.

\section{Materials and Methods}

The experiment was conducted at Agricultural Research Station Baffa Mansehra during 2008. The experiment was laid out in randomized complete block (RCB) design with split plot arrangements. There were two factors in the experiment viz. sowing dates and cultivars. Three sowing dates with 15 days intervals i.e. SD1 $=15^{\text {th }}$ March 2008, SD2 $=30^{\text {th }}$ March 2008 and SD3 $=14^{\text {th }}$ April 2008 were assigned to main plots. Six different okra cultivars i.e. $\mathrm{V} 1=$ Irka, V2 = Sabz Pari, V3 = Pusa
Green, V4 = Pusa Sawani, V5 = Green Star and V6 = Sarhad Green were assigned to sub- plots. There were eighteen treatments of different combination and each was replicated three times. Each plot was $9 \mathrm{~m}^{2}$ (5 $\mathrm{x} 1.8 \mathrm{~m}^{2}$ ) having 3 rows, each 5 meter long and $60 \mathrm{~cm}$ apart. Plant to plant distance was $20 \mathrm{~cm}$. Before sowing of crop, the land was prepared thoroughly and nitrogen, phosphorus, and potash @ 120-90-60 kg $\mathrm{ha}^{-1}$ was applied in the form of urea, triple super phosphate and potassium sulphate respectively. All phosphorus, potash and 1/2 nitrogen was applied at the time of sowing while remaining $1 / 2$ nitrogen was applied at the time of hoeing / earthing up. Sowing was done on ridges by putting three seeds per hill $20 \mathrm{~cm}$ apart, on different sowing dates. When the seedlings were $6 \mathrm{~cm}$ tall, thinning was done to leave one per hill in order to maintain the required plant population. All the recommended cultural practices were done uniformly in all the treatments. During the course of experiment, the data was recorded on number of pods plant ${ }^{-1}$, pod length $(\mathrm{cm})$, pod diameter $(\mathrm{cm})$, pod weight $(\mathrm{gm})$, plant height $(\mathrm{cm})$ at maturity, pod yield $\left(\mathrm{t} \mathrm{ha}^{-1}\right)$, seed yield $\mathrm{kg} \mathrm{ha}^{-1}$ and 1000seed weight (gm). The data were statistically analyzed using analysis of variance technique, Least Significant Difference (LSD) test was used to compare the treatment means at 5\% level of significance.

\section{Results and Discussion}

Means values of the data recorded on various growth and yield parameters are presented in Table-1.The data revealed that sowing dates and cultivars significantly affected the growth and yield parameters, while their interaction was non-significant.

\section{Number of pods plant ${ }^{-1}$}

The data presented in Table-1, revealed that maximum number of edible pods plant $^{-1}$ (32.12) were found in okra cultivars sown on $30^{\text {th }}$ March 2008, while minimum number of edible pods plant ${ }^{-1}$ (29.02) were 
recorded in cultivars sown on $14^{\text {th }}$ April, 2008. It might be due to the reason that $30^{\text {th }}$ March 2008, sowing had longer harvest duration of fresh edible pods than $14^{\text {th }}$ April 2008, sowing. These results are in agreement with the findings of [5] who recorded higher number of pods plant $^{-1}$ in okra, sown on $1^{\text {st }}$ April as compared to $15^{\text {th }}$ April. Similarly [6] observed the variation of increased fruit number plant ${ }^{-1}$ in okra with optimum planting. By comparing the mean values of okra cultivars with one another, maximum number of pods plant $^{-1}$ (32.75) were observed in cultivar Sabz Pari, closely followed by Sarhad Green (31.65), while minimum number of pods plant ${ }^{-1}$ (27.62) were recorded in cultivar Green Star. Variation in number of pods plant ${ }^{-1}$ might be due to the genetic characteristics of okra cultivars.

\section{Pod length (cm)}

The data presented in Table- 1 showed that maximum pod length $(11.12 \mathrm{~cm})$ was observed in cultivars sown on $30^{\text {th }}$ March, 2008, while minimum pod length $(10.34 \mathrm{~cm})$ was found in cultivars sown on $15^{\text {th }}$ March, 2008. These results are in agreement with the findings of [5] who noticed maximum pod length in okra, sown on $1^{\text {st }}$ April as compared to $15^{\text {th }}$ April. Similarly [7] reported that growing response of okra to different sowing dates is not uniform and found increased pod length in okra sown on $1^{\text {st }}$ April. By comparing the mean values of okra cultivars with one another, maximum pod length $(11.57 \mathrm{~cm})$ was noted in cultivar Sabz Pari, closely followed by Sarhad Green $(11.03 \mathrm{~cm})$, while minimum pod length $(9.69 \mathrm{~cm})$ was recorded in cultivar Green Star. Variation in pod length might be due to the genetic characteristics of different okra cultivars.

\section{Pod diameter (cm)}

The data presented in Table-1, showed that maximum pod diameter $(1.54 \mathrm{~cm})$ was noticed in cultivars sown on $30^{\text {th }}$ March
2008, while minimum pod diameter (1.42 $\mathrm{cm})$ was found in cultivars sown on $15^{\text {th }}$ March, 2008. These results are in agreement with the findings of [7] who reported that growing response of okra to different sowing dates is not uniform and found increased pod diameter in okra sown on $1^{\text {st }}$ April. By comparing the mean values of okra cultivars with one another, maximum pod diameter $(1.67 \mathrm{~cm})$ was recorded in cultivar Sabz Pari, closely followed by Sarhad Green $(1.56 \mathrm{~cm})$, while minimum pod diameter $(1.32 \mathrm{~cm})$ was noticed in cultivar Green Star. Variation in pod diameter can be inferred to the genetic characteristics of different okra cultivars.

\section{Pod weight (gm)}

The data presented in Table-1, revealed that the highest pod weight (15.24 gm) was recorded in cultivars sown on $30^{\text {th }}$ March 2008, while the lowest pod weight (13.48 gm) was found in cultivars sown on $15^{\text {th }}$ March, 2008. These results obtained are in consonance with the findings of [7] who reported that growing response of okra to different sowing dates is not uniform and found increased pod weight in okra sown on $1^{\text {st }}$ April. By comparing the mean values of okra cultivars with one another, the highest pod weight (16.04 gm) was recorded in cultivar Sabz Pari, closely followed by Sarhad Green (15.76 gm), whereas the lowest pod weight (11.62 gm) was recorded in cultivar Green Star. Variation in individual pod weight might be due to the genetic potential of different okra cultivars.

\section{Plant height (cm)}

The data presented in Table-1, revealed that maximum plant height $(184.28 \mathrm{~cm})$ was observed in cultivars sown on $30^{\text {th }}$ March 2008, while minimum plant height (165.18 $\mathrm{cm})$ was noted in cultivars sown on $14^{\text {th }}$ April, 2008. These results are in accordance with the findings of [5], who reported that plant height was higher in okra, sown on $1^{\text {st }}$ April as compared to $15^{\text {th }}$ April. Similarly 
[8] recorded maximum plant height in okra cultivars sown on $28^{\text {th }}$ May, while minimum in cultivars sown on $8^{\text {th }}$ June. By comparing the mean values of okra cultivars with one

Table-1: $\quad$ Effect of different sowing dates on the growth and yield of various okra cultivars.

\begin{tabular}{|c|c|c|c|c|c|c|c|c|}
\hline Treatments & $\begin{array}{l}\text { Number } \\
\text { of pods } \\
\text { plant }^{-1}\end{array}$ & $\begin{array}{l}\text { Pod } \\
\text { length } \\
(\mathrm{cm})\end{array}$ & $\begin{array}{l}\text { Pod } \\
\text { diameter } \\
(\mathrm{cm})\end{array}$ & $\begin{array}{l}\text { Pod } \\
\text { weight } \\
\text { (gm) }\end{array}$ & $\begin{array}{l}\text { Plant } \\
\text { height } \\
(\mathrm{cm})\end{array}$ & $\begin{array}{l}\text { Pod yield } \\
\left(\mathrm{t} \mathrm{ha}^{-1}\right)\end{array}$ & $\begin{array}{l}\text { Seed yield } \\
\left(\mathrm{kg} \mathrm{ha}^{-1}\right)\end{array}$ & $\begin{array}{l}\text { 1000-seed } \\
\text { weight }(\mathrm{gm})\end{array}$ \\
\hline \multicolumn{9}{|l|}{ Sowing dates } \\
\hline $\begin{array}{l}\text { SD1 }=15^{\text {th }} \\
\text { March }\end{array}$ & $30.35 \mathrm{ab}$ & $10.34 \mathrm{~b}$ & $1.42 \mathrm{~b}$ & $13.48 \mathrm{~b}$ & $172.97 \mathrm{~b}$ & $15.31 \mathrm{~b}$ & $1553.78 \mathrm{~b}$ & $78.63 \mathrm{~b}$ \\
\hline $\begin{array}{l}\mathrm{SD} 2=30^{\text {th }} \\
\text { March }\end{array}$ & $32.12 \mathrm{a}$ & $11.12 \mathrm{a}$ & $1.54 \mathrm{a}$ & $15.24 \mathrm{a}$ & $184.28 \mathrm{a}$ & $16.24 \mathrm{a}$ & $1601.92 \mathrm{a}$ & $86.92 \mathrm{a}$ \\
\hline SD3 $=14^{\text {th }}$ April & $29.02 \mathrm{~b}$ & $\begin{array}{l}10.59 \\
a b\end{array}$ & $1.47 \mathrm{~b}$ & $14.10 \mathrm{~b}$ & $165.18 \mathrm{c}$ & $14.09 \mathrm{c}$ & $1402.36 \mathrm{c}$ & $81.34 \mathrm{~b}$ \\
\hline LSD at $5 \%$ & 1.92 & 0.59 & 0.05 & 1.04 & 4.34 & 0.58 & 55.61 & 2.97 \\
\hline \multicolumn{9}{|l|}{ Cultivars } \\
\hline $\mathrm{V} 1=\mathrm{Irka}$ & $31.20 \mathrm{abc}$ & $\begin{array}{l}10.84 \\
\mathrm{bc}\end{array}$ & $1.49 \mathrm{c}$ & $\begin{array}{l}15.09 \\
\mathrm{ab}\end{array}$ & $175.66 \mathrm{bc}$ & $15.51 \mathrm{~b}$ & $\begin{array}{l}1522.36 \\
\text { bc }\end{array}$ & $85.17 \mathrm{ab}$ \\
\hline V2 = Sabz Pari & $32.75 \mathrm{a}$ & $11.57 \mathrm{a}$ & $1.67 \mathrm{a}$ & $16.04 \mathrm{a}$ & $187.17 \mathrm{a}$ & $17.50 \mathrm{a}$ & $1735.00 \mathrm{a}$ & $89.32 \mathrm{a}$ \\
\hline V3 = Pusa Green & $30.30 \mathrm{bc}$ & $\begin{array}{l}10.66 \\
\mathrm{bc}\end{array}$ & $1.45 \mathrm{c}$ & $14.38 \mathrm{~b}$ & $172.21 \mathrm{c}$ & $14.63 \mathrm{bc}$ & $\begin{array}{l}1444.22 \\
\text { cd }\end{array}$ & $82.30 \mathrm{~b}$ \\
\hline $\begin{array}{ll}\text { V4= } & \text { Pusa } \\
\text { Sawani } & \end{array}$ & $29.44 \mathrm{~cd}$ & $\begin{array}{l}10.28 \\
\mathrm{~cd}\end{array}$ & $1.37 \mathrm{~d}$ & $12.74 \mathrm{c}$ & $168.53 \mathrm{c}$ & $13.96 \mathrm{~cd}$ & $\begin{array}{l}1391.70 \\
d c\end{array}$ & $76.89 \mathrm{c}$ \\
\hline V5 = Green Star & $27.62 \mathrm{~d}$ & $9.69 \mathrm{~d}$ & $1.32 \mathrm{~d}$ & $11.62 \mathrm{~d}$ & $159.90 \mathrm{~d}$ & $13.11 \mathrm{~d}$ & $1301.09 \mathrm{c}$ & $73.74 \mathrm{c}$ \\
\hline $\begin{array}{l}\text { V6=Sarhad } \\
\text { Green }\end{array}$ & $31.65 \mathrm{ab}$ & $\begin{array}{l}11.03 \\
\mathrm{ab}\end{array}$ & $1.56 \mathrm{~b}$ & $15.76 \mathrm{a}$ & $181.38 \mathrm{ab}$ & $16.57 \mathrm{a}$ & $\begin{array}{l}1621.74 \\
a b\end{array}$ & $86.37 \mathrm{ab}$ \\
\hline LSD at $5 \%$ & 2.11 & 0.62 & 0.07 & 1.02 & 7.58 & 1.00 & 116.50 & 5.28 \\
\hline
\end{tabular}

Means followed by the same letter (s) do not differ significantly from one another at 5\% probability level, using LSD

another, maximum plant height $(187.17 \mathrm{~cm})$ was observed in cultivar Sabz Pari, closely followed by Sarhad Green $(181.38 \mathrm{~cm})$, while minimum plant height $(159.90 \mathrm{~cm})$ was recorded in cultivar Green Star. Variation in plant height might be due to the genetic characteristics of okra cultivars coupled with environment. These results are in conformity with the findings of [9] who recorded maximum plant height $(1.69 \mathrm{~m})$ in okra cultivar Green Tech, and minimum in cultivar Super Green.

\section{Pod yield (t ha-1)}

The data presented in Table-1, revealed that the highest fresh pod yield $\left(16.24 \mathrm{t} \mathrm{ha}^{-1}\right)$ was realized when okra cultivars were sown on $30^{\text {th }}$ March 2008, while the lowest fresh pod yield $\left(14.09 \mathrm{t} \mathrm{ha}^{-1}\right)$ was obtained when sown on $14^{\text {th }}$ April, 2008. These results are in conformity with the findings of [5] who recorded higher fresh pod yield in okra, sown on $1^{\text {st }}$ April as compared $15^{\text {th }}$ April. By comparing the mean values of okra cultivars with one another, it was noted that cultivar Sabz Pari gave the highest fresh pod yield (17.50 $\mathrm{t} \mathrm{ha}^{-1}$ ), followed by Sarhad Green (16.57 tons), whereas the lowest fresh pod yield (13.11 $\left.\mathrm{t} \mathrm{ha}^{-1}\right)$ was obtained from cultivar Green Star. Variation in fresh pod yield hectare ${ }^{-1}$ can be attributed to the genetic potential of various okra cultivars.

\section{Seed yield (kg ha-1)}

The data presented in Table- 1 , revealed that the highest seed yield (1601.92 $\left.\mathrm{kg} \mathrm{ha}^{-1}\right)$ was obtained from cultivars sown on $30^{\text {th }}$ March 2008, while the lowest seed yield (1402.36 $\mathrm{kg} \mathrm{ha}{ }^{-1}$ ) was obtained from okra cultivars sown on $14^{\text {th }}$ April, 2008. These results are 
in consonance with the findings of [10] who found that sowing of okra on $13^{\text {th }}$ June resulted in maximum seed yield hectare ${ }^{-1}$ as compared to other sowing dates. By comparing the mean values of okra cultivars with one another, the greatest seed yield $\left(1735.00 \mathrm{~kg} \mathrm{ha}^{-1}\right)$ was realized in cultivar Sabz Pari, followed by Sarhad Green $(1621.74 \mathrm{~kg})$, while the lowest seed yield (1301.09 $\mathrm{kg} \mathrm{ha}^{-1}$ ) was observed in cultivar Green Star. Variation in seed yield hectare ${ }^{-1}$ can be inferred to the genetic potential of various okra cultivars.

\section{0-seed weight (gm)}

The data presented in Table-1, showed that 1000-seed weight (86.92 gm) was maximum in cultivars sown on $30^{\text {th }}$ March, 2008, while minimum (78.63 gm) in cultivars sown on $15^{\text {th }}$ March, 2008. These results are in agreement with the findings of [9] who recorded maximum 100-seed weight in cultivars sown on $25^{\text {th }}$ May as compared to other sowing dates. By comparing the mean values of okra cultivars with one another, maximum 1000-seed weight (89.32 gm) was recorded in cultivar Sabz Pari, followed by Sarhad Green (86.37 gm), while the minimum1000-seed weight (73.74 gm) was observed in cultivar Green Star. These results are in agreement with the findings of [9] who recorded maximum 100-seed weight in cultivar T-13 as compared to other cultivars. Variation in 1000-seed weight can be attributed to the genetic potential of various okra cultivars.

\section{References}

1. Baloch AF (1994). Vegetable Crops. In: Horticulture. National Book Foundation: Islamabad pp 529-531.

2. Koay SH \& Chua SE (1978). Effect of fertilizers on vegetative growth and pod production in okra (Abelmoschus esculentus L.). Singapore J Prio Ind 6: 76-79.

3. Kernick MD (1961). Vegetable crops. In: Agriculture and horticultural seeds. Rome: Food and Agricultural Organization of the United Nations.

4. Tindall HD (1983). Vegetables in the Tropics. McMillan AVI pp 33: 325-327.

5. Incalcaterra G, Vetrano F, Stoffella PJ, Cantliffe DJ \& Damato G (2000). Effect of two sowing dates and plastic mulch on okra production. International Symposium on Timing of Field Prod. In: Veg. Crop, Bari, Italy, 15-18 October 1997. Acta-Horticultura No.533: 329-336.

6. Palanisamy V, Vanangamudi K, Jayaraj T \& Karivaratharaju TV (1986). Influence of date of sowing in bhindi (Abelmoschus esculentus (L).Moench). South Indian Hort 34(1): 23-25.

7. Iremiren GO \& Okiy DA (1986). Effect of sowing date on the growth, yield and quality of okra (Abelmoschus esculentus (L.) Moench. In Southern Nijeria. J of Agri Sciences U.K 106 (1): 21- 26.

8. Hussain S, Sajid M, Amin N, Alam S \& Iqbal Z (2006). Response of okra (Abelmoschus esculentus) cultivars to different sowing times. $J$ of Agricultural and Biological Sciences 1(1): 1-8.

9. Khan M (1999). Response of different cultivars of okra (Abelmoschus esculentus L.) to three different sowing dates in the mid hill of Swat Valley. MSc Thesis Deptt of Hort NWFP Agric University Peshawar.

10. Yadav SK, Dhankhar BS, Deswal DP \& Tomer RPS (2001). Effect of sowing dates and planting geometry on seed production and quality of okra (Abelmoschus esculentus (L).Moench) Indian society of seed technology, seed Research 29(2): 149-152. 